$9-1-2001$

\title{
Policy and Progress in Moroccan Agriculture: A Retrospective and Perspective
}

Channing Arndt

Purdue University

Wallace E. Tyner

Purdue University

Follow this and additional works at: https://ecommons.luc.edu/meea

Part of the Economics Commons

\section{Recommended Citation}

Arndt, Channing and Tyner, Wallace E., "Policy and Progress in Moroccan Agriculture: A Retrospective and Perspective". Topics in Middle Eastern and North African Economies, electronic journal, 3, Middle East Economic Association and Loyola University Chicago, 2001, http://www.luc.edu/orgs/meea/

This Article is brought to you for free and open access by the Journals and Magazines at Loyola eCommons. It has been accepted for inclusion in Topics in Middle Eastern and North African Economies by an authorized administrator of Loyola eCommons. For more information, please contact ecommons@luc.edu. (c) 2011 the authors 


\title{
POLICY AND PROGRESS IN MOROCCAN AGRICULTURE: A RETROSPECTIVE AND PERSPECTIVE
}

\author{
Channing Arndt, Purdue University and Wallace E. Tyner, Purdue University \\ Email: Arndt@agecon.purdue.edu
}

JEL Codes: Q1, Q2

The policy reforms in Moroccan agriculture brought about through the process of structural and sectoral adjustment and the engagements undertaken by Morocco in the context of the General Agreement on Tariffs and Trade (GATT) represent important milestones in Moroccan agricultural history (1). Since 1985, reforms have been undertaken, especially with respect to domestic agricultural markets.

Both authors have been closely involved in the reform process (Arndt since 1990 and Tyner since 1985). The process has been drawn out, halting, and highly complex. Throughout this article, we have tried to strike a balance between the need to generalize, in order to make the discussion accessible to readers unfamiliar with the evolution of Moroccan agricultural policy, and the need to present enough detail to be true to the facts. In this paper, we draw from available sources and our experience to argue three related points.

1) The impacts of reforms undertaken to date have, by and large, been positive. This reflects much more the dismal state of agricultural policy in 1985 rather than a positive rating of the reform process or the current policy environment.

2) Accordingly, further reforms, especially with respect to trade policy, are desirable.

3) Future reforms require important policy trade-offs, especially with respect to price stability for strategic agricultural commodities (bread wheat, sugar and oilseeds).

\section{Structural and Sectoral Adjustment}

At the dawn of agricultural sector adjustment in 1985, the Moroccan agricultural sector was marked by one of the highest levels of state intervention in the world. Heavy government involvement, both direct and indirect, characterized input markets, production decisions (especially in irrigated zones), marketing, and international trade. For example, the Office Nationale Interprofessionelle des Céréales et Légumineuses (ONICL) managed all imports of cereals. The Office de Commercialisation et Exportation (OCE) managed all exports. Delivery of wheat to industrial flour mills was accomplished by a byzantine system involving state run storage depots, licensed traders, the government transportation monopoly (Office Nationale de Transport $(\mathrm{ONT})$ ), and ONICL. Parastatals were the dominant providers of seed, fertilizer, and credit. Production patterns within large irrigation perimeters were dictated by the Offices Régionale de Mise en Valeur Agricole (ORMVAs). Prices, including storage and processing margins, were set by the government. Variable levy trade protection implemented through state trading broke all connection with international prices for imported products (2). Finally, a complex web of producer and consumer subsidies was required to lubricate the system. The subsidy burden on government finances in the early 1980s amounted to about 3.5 billion Dirham (DH) per annum accounting for nearly $15 \%$ of government current expenditure or roughly $3 \%$ of GDP (Crawford and Purvis, 1986). Despite all the regulation and controls in the economy at this time, the overall level of producer subsidy, in general, was not extraordinary. The main problem with the system was excessive rigidity and government controls rather than excessive levels of producer subsidization.

The era of agricultural sector adjustment began in 1985 with the first agricultural sector adjustment loan (ASAL1) from the World Bank. There were four major objectives of that loan:

1) restructure the agricultural investment program;

2) re-orient the prices and incentives framework;

3) strengthen agricultural support services including rationalizing the role of the private sector; and 
4) build institutional capacity for agricultural planning and policy analysis.

The ASAL1 loan document contained a nine page matrix of conditionality related to the four objectives, but focusing on prices and incentives. Some of the conditions were met, such as elimination of fertilizer subsidies. Another condition was to begin water charges in irrigated areas equal to the full cost of operation and maintenance plus a fraction of investment cost. That condition has not been implemented to this day. There were many other conditions involving the marketing and protection systems for agricultural commodities. Some, but not all, of these conditions were met.

In 1987, the second Agricultural Sector Adjustment Loan (ASAL2) was negotiated. Conditions in this loan included privatization of veterinary services, trade liberalization measures, domestic market reforms, data collection on cost of production, and many others. Few of the conditions were achieved in the time frame of the loan, but many of the changes were eventually adopted. In the trade area, the conditions required that agricultural commodities, other than those considered strategic (e.g., wheat, sugar, and oils), move from a "license required for import" status (effectively a quota) to free trade with border protection. This change was accomplished either in the late 1980s or in the 1990s as part of the General Agreement on Tariffs and Trade (GATT) accommodation process (depending on the commodity). Also, during this time frame, the role of ONICL began to evolve from a state trading organization for cereals to a monitoring agency. The World Bank loan also required analysis and development of programs to target and reduce consumer subsidies. In general, this condition was not met, except for a limit on the amount of subsidized flour that could be produced. Consumer subsidies on flour, sugar, and table oil continue to be a significant part of government expenditure (Tyner and Arndt estimated about 10\% in 1996).

It is interesting to compare the levels of protection and producer subsidy equivalents before and after implementation of the sectoral adjustment program. Table 1 provides the domestic to world price ratios (nominal protection) for some important agricultural commodities in both 1980-83 and 1990-93. Protection of cereals and oilseeds increased significantly while protection of meat remained at the already high levels. In other words, one "result" of sectoral adjustment was an augmentation of border protection. When one measures the totality of agricultural subsidies and protection, the same picture emerges. The producer subsidy equivalent (PSE) for cereals went from 4 to 8 percent, for meat from 28 to 44 percent, for sugar and oilseeds from 9 to 46 percent, and for primary agriculture as a whole from 10 to 25 percent (FAO, p. 52).

Table 1

Domestic to Border Price Ratios for Important Agricultural Commodities

\begin{tabular}{|l|l|l|}
\hline Commodity & $1980-83$ & $1990-93$ \\
\hline Common wheat & 1.36 & 1.95 \\
\hline Durum wheat & 1.36 & 2.40 \\
\hline Barley & 1.78 & 2.50 \\
\hline Corn & 1.05 & 2.01 \\
\hline Sunflower & 1.31 & 2.00 \\
\hline Beef & 2.24 & 2.30 \\
\hline Chicken & 2.30 & 2.32 \\
\hline
\end{tabular}

Source: FAO and Moroccan Ministry of Agriculture, Impact of the Structural Adjustment Program on Agricultural Sector Development, volume 1, 1997, p. 49. 
During the late 1980s some of the groundwork was laid for domestic policy reform that eventually was implemented in the mid1990s. Domestic market reforms were part of the conditionality in ASAL2. More details on these reforms will be provided below under GATT and post-GATT.

\section{GATT and post-GATT}

While much of the initial impetus for reform came from the international community (e.g., the World Bank) and a few individuals within government, commitment to reforming domestic market and trade policies, in the public and private sectors, both broadened and deepened in the early 1990s. For example, Morocco became a leader among the developing nations in the Uruguay round of GATT negotiations. The prominent role played by Morocco in these negotiations ultimately led to Marrakech, Morocco, being chosen as the site for the signing ceremonies for the GATT agreement in 1994.

The GATT agreement and associated country offers have been criticized on a number of grounds (Abbott, et al). One of these is dirty tariffication. Under dirty tariffication, countries (both developed and developing) sometimes established tariff ceilings that, in fact, represented higher levels of protection than had actually been applied in the country previously. Even though a base period was established in the general procedures, countries were able to craft fictitious rates higher than actual practice as their base (see also Hathaway and Ingco).

Morocco was guilty of dirty tariffication. Table 2 contains Moroccan binding protection levels for some important agricultural commodities. For many of these commodities, Morocco had never practiced protection as high as the binding levels. Yet, the calculation procedures permitted these high protection levels to be used. Even the binding levels in 2005 are higher than most protection levels applied today. So, the bottom line is that the GATT agreement does not effectively limit protection levels for Moroccan agricultural commodities.

Table 2

Moroccan GATT Tariff Ceilings for Important Agricultural Commodities

\begin{tabular}{|c|c|c|}
\hline Product & $\begin{array}{r}\text { Initial Tariff Ceiling } \\
(\%)^{*}\end{array}$ & $\begin{array}{r}\text { Ceiling After } 10 \text { Years } \\
(\%)^{*}\end{array}$ \\
\hline Wheat & 190 & 144 \\
\hline Barley & 148.5 & 113 \\
\hline Corn & 160.5 & 122 \\
\hline Rice & 217 & 165 \\
\hline Sugar & 221 & 168 \\
\hline Soybeans & 146.5 & 111 \\
\hline Sunflower & 183.5 & 139 \\
\hline Unrefined table oil & 283.5 & 215 \\
\hline Soybean meal & 113 & 86 \\
\hline
\end{tabular}




\begin{tabular}{|l||r|r|}
\hline Beef & 315 & 239 \\
\hline Lamb & 380 & 289 \\
\hline Chicken & 132.5 & 101 \\
\hline Milk & 115 & \\
\hline
\end{tabular}

\section{*In addition to these ad valorem tariff rates, an additional duty ranging from 7.5 to 15 percent is applied to all agricultural commodities.}

Source: G.A.T.T.: Engagement du Maroc, Produits Agricoles et Leurs Derivés, January 1994, p. 8.

The most significant change in border protection for Moroccan agriculture was that most of the commodities were converted from license to ad valorem protection. The process that had begun with ASAL2 in 1987 was effectively completed with the Moroccan GATT offer. Many of the commodities have very high protection levels (200 percent or more), but some were included at a 60 percent rate at the start of the Uruguay round phase in period (initial protection) to be reduced to 45 percent at the end of the phase in period (final protection). Changing all these commodities to tariff protection was a huge undertaking. However, in our view, it had large benefits particularly for relatively small volume import commodities (3). Under the old system, a license was required to import almost any commodity, and the administration often refused to grant licenses. For example, producers of mixed feed for poultry production were often refused a license to import maize in order to support domestic barley prices. However, barley is a very poor substitute for maize in poultry rations. Overall, replacement of licenses with tariffs (even large ones) led to a clearer and more predictable import structure ("transparent" is the word used henceforth in the document).

The Moroccan GATT offer used ad valorem tariffs for all commodities. However, it soon became clear that straight ad valorem tariffs, particularly given the high rates imposed, would not work in the Moroccan context. Ad valorem protection amplifies the level of domestic price instability. That is, the variability of world prices is transmitted to domestic markets amplified by the level of the tariff (Tyner and Arndt, p. 51) (4). Maintaining domestic price stability for "strategic" food commodities (wheat, sugar, and cooking oil) has, at least for the past 25 years, been very important in Moroccan politics. Government officials wanted to comply with their GATT obligations, but also felt the necessity to maintain domestic price stability.

In the 1990s, many different potential systems were analyzed (and some implemented) attempting to accomplish both objectives. However, an acceptable system was not found. So, more recently, price variability concerns have trumped GATT obligations (at least in spirit). The current protection system for "strategic" food commodities (which are the major import items) is essentially a variable levy (even though it uses tariff rates to give the appearance of similarity to an ad valorem system). Under the current system, there is no tendency for domestic prices to follow world prices in either the short or the long term. Nominal protection rates depend mostly on world price levels. As world prices decline [increase], protection rates increase [decrease].

The export side and domestic markets are another case. On the export side, substantial changes were made. State control and intervention in export markets were reduced substantially. Private exporters and export associations were given more sway in handling the whole export chain. Also, Morocco was able to complete negotiations with the European Union providing greater market access for some critical commodities like citrus.

Regarding domestic markets, beginning in the mid 1980s and continuing to the present, Morocco has taken substantial steps to liberalize domestic markets. Many of the restrictions on domestic transportation and marketing of agricultural products have been eliminated. Flour millers, for example, can purchase wheat directly from farmers or from intermediaries who purchase wheat from farmers. Government intervention in storage and grain purchase has diminished considerably. Domestic trade and marketing, including input supply, is simply much less regulated and much more flexible than was the case previously.

We turn now to an assessment of the reform measures undertaken.

\section{Impact of Reform Measures Undertaken}

Analytical efforts to track the impacts of agricultural sector reform measures in Morocco have been bedevilled by a 
lack of a solid baseline from which to compare pre with post reform situations. In the evaluation of structural adjustment programs, debates about baselines and subsequent economic performance are not at all uncommon. For example, in a major study evaluating the impact of structural adjustment in sub-Saharan Africa, Sahn, Dorosh, and Younger (1996) employ a computable general equilibrium approach arguing that this is the only way to establish a reliable counterfactual since actual economic performance post-adjustment is certain to be subject to a vast array of exogenous factors, such as changes in international prices, that are likely to influence actual economic performance. However, the approach of Sahn, Dorosh, and Younger has been strongly criticized (De Maio, Stewart, and van der Hoeven, 1999). Evaluation of the economic and social implications of various structural adjustment remains highly contentious, particularly with respect to implications for the poor.

In Morocco in the mid 1980s, the data available for evaluating the impacts of structural adjustment programs was quite thin. Since that time, substantial effort has been undertaken to improve the quality of statistics. Initial efforts focused on the level of agricultural production. Nevertheless, throughout most of the adjustment period, information crucial to the evaluation of the social impacts of policy change such as the size distribution of farms, production practices including cost of production, offfarm earnings, remittances, and consumption profiles were either spotty, dated, or non-existent.

To further complicate matters, almost all social variables in rural areas are certain to vary closely with a highly variable climate. Recently, with a new agricultural census, vastly improved information on production practices and costs of production, a series of living standards studies, and improved information on off-farm income and remittances, the raw data (including some time series insight into the impacts of climate variability) for in-depth analysis of future policy change has come available. The analytical effort necessary to synthesize this data into a coherent framework for evaluation of policy options has not yet been undertaken.

Despite these data and analytical limitations, we contend that the reforms undertaken to date have, by and large, been positive when evaluated by almost any reasonable criteria. As mentioned above, these reforms have taken place primarily in the arena of domestic market liberalization. For example, liberalization of input markets is widely regarded as a success (5).

Timeliness of input delivery and quality of inputs has improved. Partial liberalization of durum wheat markets in 1987 resulted in rapid growth in milling capacity for durum wheat (ICEA, 1996). Measures to reduce bureaucratic burdens in export markets and allow farmers greater choice in crop allocation decisions in irrigated zones are also widely viewed as positive. A study by Ben Senia (1993) found that the maintenance of pre-adjustment policies would have been very costly in terms of public expenditure and would have had minor welfare impacts on small farmers of indeterminate sign.

The analyses undertaken by Ben Senia were purely static, yet a major intention of any economic reform program is to increase the rate of economic growth. While the reform program is not the sole factor determining economic growth, it is the case that primary agriculture and food processing have become more dynamic sectors in the economy since the reform program began in 1985. Table 3 shows shares of primary agriculture in GDP and agricultural exports in GDP for various time periods. Prior to 1985 , the share of primary agriculture in GDP and the share of primary agricultural and processed foods exports in GDP were declining. The figures indicate an inflection point around 1985. Since the mid 1980s, the share of primary agriculture in GDP and the share of primary agricultural and processed food exports in GDP has been essentially constant. Over the period 1987 to 1996 , real GDP growth averaged 3.6\% implying real growth in agricultural value added and exports at roughly the same rate during that period. In contrast, real GDP grew at about a 2.9\% rate between 1977 and 1985. Due to these increases in the value of agricultural and processed food exports and declines in the real value of mineral exports (primarily phosphates), the share of agriculture in total merchandise exports increased to $32.0 \%$ for the period 1991 to 1996 compared with $27.7 \%$ for the period 1980 to 1985 . The gains in primary agriculture and processed food exports are impressive, particularly in light of the indirect penalization of export oriented agricultural commodities stemming from the increase in protection accorded to import competing agricultural commodities over the structural adjustment period. These export gains are likely to be related to the reform program.

Table 3

Share of Agricultural Exports in GDP and Primary Agriculture in GDP and Rural Population in Total Population

\begin{tabular}{|l|c|c|c|}
\hline & $1960-1970$ & $1980-1985$ & $1991-1996$ \\
\hline Ag Export Share & 8.2 & 4.4 & 4.5 \\
\hline Primary Ag GDP Share & 21.9 & 17.2 & $17.1^{*}$ \\
\hline
\end{tabular}




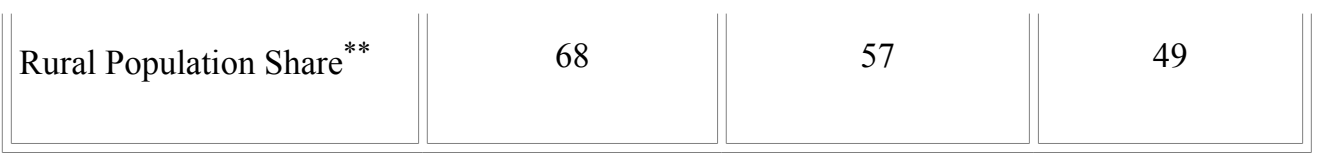

* Regression analysis indicates a mild increase in the share of primary agriculture in GDP over the period $1985-1996$.

** The first column is the average of shares from the 1960 and 1971 population censuses, the second column is from the 1982
census, and the third column is from the 1994 census.

Source: Annuaire Statistique du Maroc, various years.

The figures in Table 3 highlight the continuing importance of agriculture in the Moroccan economy. Moreover, roughly half of employment is currently found in primary agriculture and agricultural processing, with the rural poor figuring prominently among this group. A more dynamic and efficient agriculture has the potential to contribute to both growth and equity. This view of agriculture as a contributing sector, as opposed to a sector whose decline must be carefully managed by the state, provided one of the rationales for the major push for domestic market liberalization that occurred in the 1990s and underscores the need for further reform.

\section{The Need for Further Reform}

While the domestic reforms mark a positive step forward, continued relatively rapid growth in the agricultural sector requires continued policy reform, particularly with respect to international trade. Reform of border protection policy is important for three reasons. First, failure to enact trade policy reform is currently circumscribing the scope and reducing the impact of domestic policy reform. For example, insulating trade policies in oilseeds leaves one firm in a monopoly or near monopoly position with respect to crushing oilseeds and refining and retailing vegetable oil. Full domestic market liberalization without reform of the insulating trade policies (especially the rapid increase in protection rates up the value added chain) would simply replace an effectively state run system with a private monopoly.

Second, to contribute more forcefully to the economic development of Morocco, the agricultural sector must forge closer links with the global economy. In order for sectors with comparative advantage to expand, sectors without comparative advantage must be permitted to contract. In too many cases, current trade policy ruptures, rather than forges, these links and encourages crops without comparative advantage. This expansion/contraction relationship is particularly obvious in agriculture. For example, due to border protection, wheat and sugar occupy a substantial share of scarce irrigated land (6). Since the inception of a high protection/production promotion policy in oilseeds in the mid 1980s, oilseeds planted area went from nearly zero to more than 200,000 hectares of some of the best dry land in Morocco in 1992. In addition, oilseeds now occupy a small but growing share of available irrigated ground. These crops, all highly protected, displace other crops that international markets value more highly.

Third, available evidence indicates that decreases in protection rates for agricultural products tend strongly to increase the welfare of urban households and may or may not harm farm households. Generally, the equity implications of reduced border protection in Morocco appear to be favorable. For example, Serghini (1993), using a general equilibrium approach, finds that reductions in protection rates for cereals tend to increase the welfare of small farmers and reduce the welfare of larger farmers. Urban dwellers gain substantially. These effects occur for two reasons. First, small farmer households are more likely to be net buyers of cereals. As a result, lower cereals prices are favorable to these households. Second, even if small farms are net surplus in cereals production, they still tend to own relatively more assets specific to livestock production and fewer assets specific to cereals production than large farmers. Urban welfare gains following reductions in food prices following the trade policy change result in a large increase in demand for livestock products. This effect also favors small farmers.

The small farmer household is a very important segment. The recent agricultural census indicates that $55 \%$ of all farmers are, in fact, small- operating on three hectares or less (Ministry of Agriculture, Rural Development and Fisheries, 1998). A further $15 \%$ of farmers are only slightly larger- operating on three to five hectares. While quality of land and off-farm earning opportunities are clearly factors in household welfare, farm size remains a relatively robust indicator of household wealth. Small farmers tend to be poor. In contrast, farm households operating more than 20 hectares represent only $4 \%$ of the total; however, they cultivate approximately one third of available agricultural land.

In a second analysis, Arndt, Serghini, and Tyner (1995) employ the model developed by Serghini to examine the impacts of reduced maize protection levels. They find that a $15 \%$ reduction in maize protection either improves or leaves unchanged welfare for all households in the model. It is very unusual to find, in a model with substantial household detail (the model included four rural households and one urban household), a policy change that fails to make at least one household worse off. However, these results are indicative of the (static) efficiency gains (dynamic gains would be larger) and positive distributional 
impacts from well managed trade policy reform.

In short, while information is far from complete, the available information provides support for cautious and steady continuation of the liberalization process.

\section{Prospects for the Future}

We feel that Morocco's concerns regarding price stability need to be addressed in order to make progress in reducing protection levels and furthering market reforms. However, it is also necessary for Morocco to accept a certain level of price variability if the benefits of a market oriented system are to be captured. For example, left from the French days, there is a view in some quarters that the prices for basic commodities should be the same all over the country. However, any market solution would result in prices that differed across regions and through time. Market actors would have to be compensated for transportation and storage costs.

Elimination or near elimination of world price variability through a form of variable levy protection at the border is also inconsistent with a market regime. If world price variability is eliminated or nearly so, incentives for importers to find the lowest cost product on world markets is eliminated or nearly eliminated as well (this is currently the case for strategic commodities). Private importing behavior is almost certain to be highly inefficient. One must either live with these inefficiencies (and other concomitant inefficiencies downstream such as market power for some agro-processors) or accept a higher degree of domestic price variability.

\section{Conclusions}

In order to get the liberalization process moving again, we believe that Morocco, the World Trade Organization, and the World Bank need to accept the Moroccan desire for relatively stable domestic prices of certain strategic commodities. In turn, the Moroccans need to accept some price variability in all commodities and that not all commodity prices require policy interventions aimed at enhancing price stability. Ad valorem tariffs would work fine for most commodities if the protection level were reduced such that variability in world prices was not so amplified on domestic markets. For "strategic" commodities, one might consider a protection policy with a stabilization element if the level of the protection were considerably lower and if sufficient variability were transmitted to maintain efficient linkages to world markets. Morocco could get the improved resource allocation from more appropriate pricing without suffering the instability associated with ad valorem protection. The Moroccan government also needs to acknowledge the efficiency gains that could accrue from lower protection of some agricultural commodities.

Finally, improved understanding of the implications of various policy alternatives would be helpful. This is especially true with respect to policy reform in wheat/flour. As emphasized earlier, the new data from the agricultural census and a recent series of studies of production activities in rural areas provide the best opportunity yet to ascertain the implications of alternative wheat/flour protection policies (both protection level and implied domestic price volatility). This opportunity should be capitalized upon. The important point is for Morocco to develop a game plan that is both prudent and puts the country on the path to faster economic growth in agriculture.

Acknowledgments: The authors would like to thank an anonymous reviewer, as well as the MEEA volume and series editors, for pertinent comments that substantially strengthened the paper. All remaining errors and omissions are the sole responsibility of the authors.

\section{REFERENCES}

Abbott, Philip; Hertel, Thomas; Masters, William; Paarlberg, Philip; Sanders, John; and Tyner, Wally. "International Trade" in Food System 21: Gearing Up for the New Millennium. EC-710, November 1997.

Arndt, Channing, Hassan Serghini, and Wallace E. Tyner. "Analysis of the Impacts of Reducing Maize Protection Levels on the Moroccan Poultry Sector." Department of Agricultural Economics, Purdue University, Staff Paper 95-7. July, 1995.

Ben Senia, Mohamed. "Impact de l'Ajustement Structurel Agricole sur les Niveaux de Vie des Ménages au Maroc." United States Agency for International Development, Rabot, September 1993.

Crawford, Paul R. and Malcolm J. Purvis. "The Agricultural Sector of Morocco: A Description." Annex C: Country Development Strategy Statement. United States Agency for International Development, Rabat, Morocco. 1986.

De Maio, L., F. Stewart, and R. van der Hoeven. "Computable General Equilibrium Models, Adjustment and the Poor in Africa." 
World Development, 27(3), March 1999, pages 453-70.

Food and Agricultural Organization of the United Nations and Moroccan Ministry of Agriculture. L'Impact du Programme d'Adjustement Structurel sur le Developpement du Secteur Agricole, Rapport Principal, Projet FAO/TCP/MOR/4453(A), May 1997.

Hathaway, Dale E. and Merlinda D. Ingco. "Agricultural Liberalization and the Uruguay Round." Martin, Will and L. Alan Winters eds. The Uruguay Round and the Developing Countries. Cambridge; New York and Melbourne: Cambridge University Press, 1996, pages 30-58.

ICEA Enterprises. "Impact de la Libéralisation sur le Marché du Blé Tendre au Maroc." April, 1996.

Ministry of Agriculture, Rural Development, and Fisheries. Census of Agriculture: Preliminary Results. Direction of Planning and Economic Affairs. September, 1998.

Sahn, D.E., P. Dorosh, and S. Younger. "Exchange Rate, Fiscal and Agricultural Policies in Africa: Does Adjustment Hurt the Poor?" World Development, 24(4), April 1996, pages 719-47.

Serghini, Hassan. "Trade and Price Policy and Livestock-Cereal Interactions in Domestic Markets." Ph.D. Dissertation, Department of Agricultural Economics, Purdue University. December 1993.

Tyner, Wallace E. and Arndt, Channing. "Moroccan Policy Reform in Cereals, Sugar, and Oilseeds." Associates for International Resources and Development, July, 1996. Paper prepared as part of a World Bank mission to Morocco, 89 pages.

\section{END NOTES}

1. Unless qualified, agriculture is defined broadly to encompass input markets, and product production, marketing and processing.

2. In a variable levy system, a target domestic price for the imported commodity is chosen. The levy is then simply the difference between the local currency CIF price and the target price.

3. For reasons explained later, large volume agricultural import commodities (the strategic commodities) have in effect continued to employ variable levy protection.

4. Formally, if $t$ denotes tariff rate, $\sigma$ denotes standard deviation, $\mathrm{p}$ denotes price and subscripts $\mathrm{d}$ and $\mathrm{w}$ denote domestic and world respectively, then if $\mathrm{p}_{\mathrm{d}}=\mathrm{p}_{\mathrm{w}}(1+\mathrm{t})$, then $\sigma_{\mathrm{d}}=(1+\mathrm{t}) \sigma_{\mathrm{w}}$.

5. This is the observation of the authors and other economists working in Morocco.

6. The Direction de la Production Végétale of the Ministry of Agriculture estimates irrigated area planted to sugar cane, sugar beat, hard wheat, soft wheat, maize, and oilseeds (all highly protected crops) to be more than 350,000 hectares. This amounts to more than one third of total irrigated area. At the margin, there is no doubt that other crops are valued more highly by international markets than these crops. 